\title{
Changes in Radiologia Brasileira for 2015
}

Mudanças na Radiologia Brasileira para 2015

\section{Edson Marchiori ${ }^{1}$}

The year has begun with encouraging news about the indexing of our journal. PubMed Central has approved the scientific merit of Radiologia Brasileira, opening the way to the final indexing in PubMed and later in ISI.

The journal indexing in internationally recognized databases has been a top priority of the editors and members of the current and recent boards of directors of Colégio Brasileiro de Radiologia e Diagnóstico por Imagem. Such an objective has been shared with practically all the most important national and international medical journals ${ }^{(1)}$.

Researchers in the field of Radiology, particularly those participating in stricto sensu post-graduation programs evaluated by Capes, benefit greatly from such advances in the journal qualifying, not only with the evaluation of the programs which they belong to, but also with their personal evaluation as they apply for research scholarships to funding bodies. As a counterpart, the community may contribute to the development of this process: the only way up to ranking, improving the journal impact is that it be increasingly cited in our scientific papers published by other indexed journals. This is the way for the journal to get solid and consistent recognition in the international scientific scenario ${ }^{(2)}$.

Also, a range of measures were required for the journal to comply with international models. One of the most recent measures is the end of the case reports. Most of American, European and Asian journals do not publish case reports anymore, opening space for publication of more elaborate articles considered as more relevant, such as original articles and review articles.

However, the reported cases are not devoid of value: many readers appreciate them and benefit from the information provided by case reports. In an attempt to not completely deprive the read-

1. Editor for Radiologia Brasileira. E-mail: edmarchiori@gmail.com. ers of such information, we will start publishing special cases under the form of Letters to the Editor, limiting the number of figures as well as texts size, sticking only to the most relevant information and to the most pertinent images aiming at more practicality and objectivity. The already accepted case reports may be converted into this new model of Letter to the Editor, which will greatly speed up the time for their publication, since in this transition period only one case report will be published while the number of Letters to the Editor will be much greater. The rules can already be found at the site and in the present issue of Radiologia Brasileira. Additionally, some letters published in this issue ${ }^{(3-7)}$ may serve as models for the authors. The reviewers must be alert to what is expected from this new modality: concise texts highlighting the most relevant characteristics of the case and of the disease, and not an extensive literature review on the subject.

The Editor and the CBR board of directors need, and count on, the help of all to make the journal not only compliant with the indexing rules, but also, and most important, useful and enjoyable to our main target - the reader.

\section{REFERENCES}

1. Marchiori E. A difícil indexação da Radiologia Brasileira. Temos como colaborar? Radiol Bras. 2011;44(2):v.

2. Marchiori E. Radiologia Brasileira: boas notícias para os pesquisadores nacionais. Radiol Bras. 2013;46(3):v.

3. Silva Junior GM, Zanetti GMR, Barillo JL, et al. Tumor neuroectodérmico primitivo periférico de parede torácica em adulto jovem. Radiol Bras. 2015;48:59-60.

4. Franca PMV, Ferreira CS, Figueiredo R, et al. Melorreostose. Radiol Bras. 2015; 48:60-1.

5. Rosa RFM, Targa LV, Altmayer SPL, et al. Achados pré e pós-natais de um gêmeo fusionado dicephalus tetrabrachius-dipus apresentando uma hérnia diafragmática. Radiol Bras. 2015;48:61-2.

6. Martins MM, Francisco FAF, Alfenas R, et al. Hemangioma cavernoso do espaço epidural da coluna vertebral: aspectos de imagem na ressonância magnética. Radiol Bras. 2015;48:62-3.

7. Niemeyer B, Marchiori E. Pilomatricoma gigante: achados nas sequências convencionais de ressonância magnética e na difusão. Radiol Bras. 2015;48:63-4. 